JOURNAL

OF TOURISM

AND ECONOMIC
Journal of Tourism and Economic Vol.4, No.2, 2021, Page 187-197

ISSN: 2622-4631 (print), ISSN: 2622-495X (online)

Email: jurnalapi@gmail.com

Website: http://jurnal.stieparapi.ac.id/index.php/JTEC

DOI: https://doi.org/10.36594/jtec.v4i2.127

\title{
PENGARUH RASIO KEUANGAN TERHADAP HARGA SAHAM (STUDI PADA PERUSAHAAN SEKTOR PERTAMBANGAN MINYAK YANG TERDAFTAR DI BURSA EFEK INDONESIA TAHUN 2014-2018)
}

\author{
Sulistiono \\ Universitas Proklamasi 45 Yogyakarta \\ threesulis95@gmail.com \\ Bambang Sugeng Dwiyanto \\ Universitas Proklamasi 45 Yogyakarta
}

\begin{abstract}
Stock price fluctuations are natural and almost occur in all companies in various sectors, including companies in the oil mining sector so that price changes affect the company's financial performance and stock prices which can be analyzed fundamentally using financial ratios to aspects in the financial statements. The framework of this research is to analyze the effect of financial ratios on stock prices. The population and sample used are oil mining sector companies listed on the Indonesia Stock Exchange 2014-2018. The sampling method used is purposive sampling or judgmental sampling. Sources of data used are secondary data in the form of financial statements. The tool used for data collection is through the method of observation and analysis of the company's financial statements. The results showed, based on the t test value, stock prices were positively influenced by Return on Equity (ROE), Book Value (BV) and Price to Book Value (PBV), while negatively influenced by Debt To Equity Ratio (DER) and Net Profit. Margins (NPM). Based on the F test value, stock prices are positively influenced by ROE, DER, NPM, Earnings Per Share (EPS), $B V$, and $P B V$. Based on the coefficient of determination test (R2), stock prices are strongly influenced by ROE, DER, NPM, BV, and PBV by $91.5 \%$ and influenced by other variables by $8.5 \%$.
\end{abstract}

Keywords: Fluctuations, Stock Prices, Financial Statements, Financial Ratios 


\begin{abstract}
ABSTRAK
Fluktuasi harga saham adalah hal yang bersifat wajar dan hampir terjadi diseluruh perusahaan dalam berbagai sektor, termasuk perusahaan di sektor pertambangan minyak sehingga perubahan harganya mempengaruhi kinerja keuangan perusahaan dan harga saham yang dapat di analisis secara fundamental menggunakan rasio keuangan terhadap aspek-aspek dalam laporan keuangan. Kerangka pemikiran pada penelitian ini untuk menganalisis pengaruh rasio keuangan terhadap harga saham. Populasi dan sampel yang digunakan adalah perusahaan sektor pertambangan minyak yang terdaftar di Bursa Efek Indonesia Tahun 2014-2018. Metode pengambilan sampel yang digunakan adalah purposive sampling atau judgemental sampling. Sumber data yang digunakan adalah data sekunder berupa laporan keuangan. Alat yang digunakan untuk pengumpulan data melalui metode observasi dan analisis terhadap laporan keuangan perusahaan. Hasil penelitian menunjukkan, berdasarkan nilai uji t harga saham secara positif dipengaruhi oleh Return on Equity (ROE), Book Value (BV) dan Price to Book Value (PBV), sedangkan secara negatif dipengaruhi oleh Debt To Equity Ratio (DER) dan Net Profit Margin (NPM). Berdasarkan nilai uji F harga saham secara positif dipengaruhi oleh ROE, DER, NPM, Earnings Per Share (EPS), BV, dan PBV. Berdasarkan uji koefisien determinasi $\left(\mathrm{R}^{2}\right)$ harga saham dipengaruhi sangat kuat oleh ROE, DER, NPM, BV, dan PBV sebesar 91,5\% dan dipengaruhi oleh variabel lain sebesar $8,5 \%$.
\end{abstract}

Kata kunci : Fluktuasi, Harga Saham, Laporan Keuangan, Rasio Keuangan 


\section{PENDAHULUAN}

Keputusan investasi terhadap suatu saham perusahaan tertentu harus didahului oleh suatu proses analisis fundamental yang diperkirakan akan mempengaruhi harga saham. Salah satu investasi yang banyak diminati oleh para investor adalah investasi saham pada perusahaan go public. Menurut Kasmir (2008 dalam Wardani et al., 2015) "saham perusahaan go public merupakan jenis saham komoditas investasi tergolong berisiko tinggi, karena sifat komoditasnya sangat peka terhadap perubahan dibidang politik, ekonomi, dan perubahan yang terjadi didalam perusahaan". Salah satu jenis perusahaan go public tersebut adalah perusahaan sektor pertambangan minyak.

Terjadinya perubahan harga saham secara fundamental dapat dijelaskan menggunakan teori sinyal atau signalling theory, sebagai dasar bagi perusahaan ketika memberikan sinyal mengenai kinerja keuangan untuk dapat menarik minat para investor supaya berinvestasi pada perusahaan dengan menggunakan laporan keuangan sebagai bahan pertimbangan (Ramadhana et al., 2018). Menurut Brigham and Ehrhardt (2005 dalam Novia, 2018) Signalling theory digunakan untuk memberikan petunjuk bagi investor tentang bagaimana prospek perusahaan dimasa depan, yaitu menjelaskan bahwa perusahaan mempunyai dorongan untuk memberikan informasi laporan keuangan pada investor disebabkan terdapatnya asimetri informasi antara perusahaan dan investor karena manajemen mengetahui lebih banyak informasi mengenai perusahaan dan prospeknya dimasa yang akan datang daripada investor.

Asimetri informasi terjadi karena adanya kelompok investor yang memiliki informasi dan kelompok investor yang tidak memiliki informasi tentang prospek perusahaan, sehingga menyebabkan adanya perbedaan gap diantara investor. Kelompok investor yang memiliki informasi akan membeli saham yang nantinya akan memberikan return, sedangkan kelompok investor yang kurang memiliki informasi akan membeli saham secara sembarangan. Akibatnya, kelompok investor yang tidak memiliki informasi ini akan meninggalkan pasar perdana karena lebih banyak kerugian (Ritter, 2004; Gao et al.,2008 dalam Safitri, 2013).

Harga saham menurut Susilo (2009 dalam Ekawati, 2017) terjadi karena adanya permintaan dan penawaran atas saham. Pada saat permintaan saham meningkat, maka harga saham akan cenderung naik. Sebaliknya, pada saat banyak orang menjual saham, maka harga saham akan cenderung turun. Penentuan harga saham didasarkan pada kinerja perusahaan yang dapat dilihat dari laporan keuangan perusahaan. Untuk menilai laporan keuangan suatu perusahaan dapat dilakukan dengan analisis rasio keuangan .

Fluktuasi harga saham menaik (uptrend) atau menurun (downtrend) adalah hal yang bersifat wajar dan hampir terjadi diseluruh perusahaan dalam berbagai sektor, termasuk perusahaan di sektor energi khususnya sektor pertambangan minyak. Menurut pendapat Senior Analyst Research Division Anugerah Sekuritas Indonesia Bertoni Rio yaitu, harga saham emiten minyak lebih banyak "tertekan" oleh pergerakan harga spot minyak mentah dibanding faktor internal emiten. Meskipun harga minyak mentah tidak selalu mempengaruhi harga saham emiten, tetapi ekspektasi pasar sering dipengaruhi oleh sentimen eksternal, sehingga sering membayangi pergerakan harga saham yang menimbulkan tingkat kecemasan tinggi seperti: kecemasan terhadap tensi perang dagang, penguatan mata uang dan kenaikan suku bunga yang akhirnya dapat melemahkan harga saham emiten minyak. Harga minyak yang menanjak bisa berdampak positif 
terhadap laporan keuangan emiten. Jika laporan keuangan positif, maka harga saham emiten minyak akan naik (Pertiwi, 2018).

Harga minyak mentah dunia menurut Pahl dan Ritcher (2009 dalam Ramli, 2016) adalah hasil dari transaksi yang terjadi secara terus-menerus diseluruh belahan dunia, pada setiap tingkatan distribusi dari penghasil minyak mentah sampai ke konsumen individu, yang kemudian dijadikan patokan dalam futures market. WTI (West Texas Intermediate) yang diperdagangkan di NYMEX (New York Merchantile Exchange) lebih banyak dinotasikan sebagai barometer harga minyak mentah dunia dibandingkan Brent Crude yang diperdagangkan di IPE (London's International Petroleum Exchange). Menurut penelitian yang dilakukan oleh Huang et al. (1996 dalam Whinston and Green, 1995 dalam Ramli, 2016) pada NYMEX (New York Merchantile Exchange) periode 1983-1990, dijelaskan bahwa minyak bersama-sama dengan modal (capital), tenaga kerja (labor) dan persediaan bahan baku mentah (inventory) merupakan komponen penting dari sebuah proses produksi sehingga perubahan harganya mempengaruhi kinerja keuangan perusahaan. Kenaikan harga minyak mentah dunia yang hingga saat ini masih belum ada alternatif penggantinya mengakibatkan naiknya biaya produksi, yang kemudian mengakibatkan berkurangnya cash flow sehingga berdampak pada penurunan harga saham. Saat harga saham menurun, maka secara otomatis saham perusahaan akan sepi peminat di bursa efek. Para investor tidak tertarik untuk berinvestasi dengan membeli saham perusahaan yang harganya tidak stabil dan cendrung menurun.

Tujuan dilakukannya penilaian terhadap kinerja perusahaan adalah sebagai dasar atas pengambilan keputusan bagi investor. Penilaian dilakukan melalui datadata yang disajikan dalam laporan keuangan. Terdapat dua macam analisis yang digunakan dalam melakukan penilaian, yaitu analisis fundamental dan analisis teknikal. Analisis teknikal yaitu analisis yang menggunakan data pasar saham yang meliputi harga, volume transaksi dan waktu (trend naik atau turun). Analisis fundamental yaitu analisis terhadap aspek-aspek dalam laporan keuangan. (Hidayat, 2018).

Ada sejumlah faktor mendasar yang dapat mengakibatkan harga saham naik ataupun turun, yaitu faktor internal dan faktor eksternal. Faktor internal adalah faktor yang timbul dari dalam perusahaan berbentuk kebijakan yang diambil jajaran manajemen sehingga dapat mengubah hal-hal yang sifatnya fundamental dalam perusahaan, seperti akuisisi, merger, right issue, atau divestasi. Sedangkan faktor eksternal bersumber dari luar perusahaan dan sulit diatasi seperti masalah yang berhubungan dengan ekonomi makro dan lebih dominan dalam mempengaruhi harga saham. Diantara beberapa faktor, yang paling menjadi sorotan adalah tingkat dividen tunai, tingkat rasio utang, rasio nilai buku, dan tingkat laba bersih perusahaann. Performa atau kinerja perusahaan juga menjadi salah satu hal yang mempengaruhi harga saham, sebab performa perusahaan dijadikan acuan bagi para investor maupun analis fundamental dalam melakukan pengkajian terhadap saham perusahaan (cermati.com, 2017).

\section{TINJAUAN LITERATUR}

\section{Return on Equity (ROE)}

Return On Equity (ROE) menurut Fakhruddin dan Hadianto (2001 dalam Takarini \& Hendrarini, 2011) adalah rasio untuk mengukur kemampuan perusahaan memperoleh laba yang tersedia bagi pemegang saham perusahaan. Semakin tinggi tingkat ROE maka keuntungan yang diperoleh bagi pemegang saham tinggi dan saham perusahaan tersebut akan diminati oleh investor sehingga harga saham akan naik. 
Menurut Suad Husnan keberhasilan kinerja keuangan suatu perusahaan dapat dilihat dari ROE yang dimiliki oleh perusahaan. ROE merupakan hal yang penting dan diperhatikan banyak pihak baik itu investor dan kreditur. Sedangkan menurut Sofyan Besarnya ROE sangat dipengaruhi oleh besarnya laba yang diperoleh perusahaan, semakin tinggi laba yang diperoleh maka akan semakin meningkatkan ROE (Suad Husnan, 2001; Sofyan, 2007 dalam Moeljadi, 2017).

Menurut Fahmi (2014 dalam Hidayat, 2018) Jika hasil perhitungan ROE mendekati 1 atau lebih maka menunjukan semakin efektif dan efesien penggunaan ekuitas perusahaan untuk menghasilkan pendapatan, jika ROE mendekati 0 berarti perusahaan tidak mampu mengolah modal yang tersedia secara efesien. Rumus yang digunakan untuk menghitung ROE adalah:

$$
R O E=\frac{\text { Laba bersih }}{\text { Modal }} x 100 \%
$$

\section{Debt To Equity Ratio (DER)}

Debt to equity ratio (DER) merupakan rasio utang yang diukur dari perbandingan utang dengan ekuitas (modal sendiri). Tingkat DER yang aman biasanya kurang dari 50 persen. Semakin kecil DER semakin baik bagi perusahaan, maka berarti sebagian struktur modal perusahaan terdiri dari equity sehingga risiko finansial rendah, ini dapat menaikkan harga saham di pasar modal (Fakhruddin dan Hadianto, 2011 dalam Takarini \& Hendrarini, 2011). Sedangkan semakin tinggi DER menunjukkan tingginya ketergantungan permodalan perusahaan terhadap pihak luar, sehingga beban perusahaan juga semakin berat. Tentunya hal ini akan mengurangi hak pemegang saham dalam bentuk dividen (Ekawati, 2017).

Menurut Hidayat (2018 dalam Ekawati, 2017) semakin tinggi rasio, maka semakin besar dana yang diambil dari luar.
Semakin rendah rasio maka semakin baik kemampuan perusahaan dalam membayar kewajibannya, karena tingkat utang yang digunakan kecil maka tingkat bunga yang dibayarkan juga kecil. Semakin kecil rasio ini berarti kondisi perusahaan semakin baik karena modal untuk menjamin utang lancar masih cukup besar. Batas terendah dari rasio ini adalah $100 \%$ atau $1: 1$. Menurut Harahap (2010 dalam Ekawati, 2017) Rumusan untuk mencari DER yaitu:

$$
\text { DER }=\frac{\text { Total utang }}{\text { Modal }} \times 100 \%
$$

\section{Net Profit Margin (NPM)}

Menurut Sutrisno Net Profit Margin (NPM) merupakan rasio untuk mengukur laba operasi bersih setiap rupiah penjualan, semakin besar NPM maka semakin baik perusahaan untuk menghasilkan keuntungan dibanding dengan penjualan yang dicapai dan investor akan semakin tertarik sehingga harga saham akan naik. Menurut Mais Net Profit Margin (NPM) yang tinggi dapat meningkatkan harga saham karena saham yang disukai oleh investor adalah saham yang perusahaannya sehat yaitu mempunyai kemampuan menghasilkan laba yang tinggi. Dengan meningkatnya NPM maka akan meningkatkan earning perusahaan sehingga akan meningkatkan kekayaan pemegang saham Menurut (Sutrisno, 2001; Mais, 2005 dalam Takarini \& Hendrarini, 2011).

Menurut Kamaludin (2005 dalam Istanti, 2015) :Net Profit Margin (NPM) adalah rasio yang menunjukkan kemampuan perusahaan dalam menghasilkan laba bersih yang tersedia bagi pemegang saham umum terhadap penjualan, yang dirumuskan sebagai berikut:

$$
N P M=\frac{\text { Laba bersih }}{\text { Penjualan }} x 100 \%
$$




\section{Earnings Per Share (EPS)}

Earning Per Share (EPS) menurut Darmadji dan Fakhruddin (2001 dalam Takarini \& Hendrarini, 2011) merupakan rasio yang menunjukkan berapa besar keuntungan (return) yang diperoleh investor per saham. semakin tinggi nilai EPS maka semakin besar laba yang disediakan untuk pemegang saham. Menurut Fahmi (2015 dalam Hikmah, 2018) Teori signal (signaling theory) menyebutkan bahwa tingginya nilai EPS perusahaan dapat memberikan signal yang baik kepada para investor karena pada umumnya para investor tertarik dengan EPS yang besar. EPS yang besar merupakan salah satu indikator keberhasilan suatu perusahaan. Semakin tinggi nilai EPS perusahaan semakin tinggi pula laba yang akan dibagikan kepada pemegang saham dan akan meninggikan harga saham perusahaan. Menurut Darmadji dan Fakhrudin (2012 dalam Hidayat, 2018) Kecilnya angka EPS suatu perusahaan menggambarkan bahwa kecil kemungkinan investor menerima laba. EPS yang menurun cenderung membuat harga saham menurun. Semakin besar ratio EPS maka semakin baik kinerja perusahaan dalam memberikan laba kepada pemegang sahamnya, dan nilai EPS yang besar akan lebih diminati oleh investor karena laba yang akan diberikan menjanjikan. Rumus yang digunakan dalam menghitung EPS adalah:

$$
E P S=\frac{\text { Laba bersih }}{\text { Jumlah saham beredar }}
$$

\section{Book Value (BV)}

Menurut Tryfino Book Value (nilai/harga buku per lembar saham) pada dasarnya mewakili jumlah aset/ekuitas yang dimiliki perusahaan tersebut. Secara normal, book value suatu perusahaan akan terus naik seiring dengan naiknya kinerja perusahaan demikian pula sebaliknya, sehingga book value ini penting untuk mengetahui kapasitas dari harga per lembar suatu saham serta dalam penentuan wajar atau tidaknya harga saham di pasar. Menurut Sihombing Book Value (BV) atau Nilai Buku suatu perusahaan adalah modal pemegang saham (shareholder's equity). Modal pemegang saham adalah jumlah aset-aset perusahaan (company's assets) dikurangi dengan kewajiban. Sedangkan menurut Jogiyanto nilai buku (book value) per lembar saham menunjukkan aktiva bersih (net assets) yang dimiliki oleh pemegang saham dengan memiliki satu lembar saham. Karena aktiva bersih adalah sama dengan total ekuitas pemegang saham, maka nilai buku per lembar saham adalah total ekuitas dibagi dengan jumlah saham yang beredar. Book Value dihitung dari pembagian jumlah keseluruhan ekuitas perusahaan dengan jumlah saham yang beredar pada perusahaan yaitu (Tryfino, 2009; Sihombing, 2008; Jogiyanto, 1998 dalam Mulia \& Nurdhiana, 2010):

$$
B V=\frac{\text { Total modal }}{\text { Jumlah saham beredar }}
$$

\section{Price to Book Value (PBV)}

Price to Book Value (PBV) adalah rasio yang digunakan untuk mengukur nilai ekuitas perusahaan pada harga pasar dibagi dengan nilai buku ekuitas perusahaan. Nilai pasar ekuitas diperoleh dengan mengalikan terlebih dahulu harga pasar terhadap jumlah saham beredar lalu dibagi dengan total ekuitas perusahaan. PBV yang rendah menandakan bahwa harga saham bersangkutan undervalued dan begitu sebaliknya. Adapun formula yang digunakan untuk menghitung rumus PBV adalah sebagai berikut (Damodaran,2006; Agrawal, 1996 dalam Apsara \& Indriani, 2017):

$$
P B V=\frac{\text { Harga pasar ekuitas }}{\text { Nilai buku }}
$$




\section{METODE PENELITIAN}

\section{Kerangka Penilitan}

Kerangka penelitian untuk menganalisis pengaruh rasio keuangan terhadap harga saham pada perusahaan sektor pertambangan minyak yang terdaftar di Bursa Efek Indonesia Tahun 2014-2018 yang menggambarkan hubungan antara variabel bebas (variabel independen) terhadap variabel terikat (variabel dependen) adalah sebagai berikut:

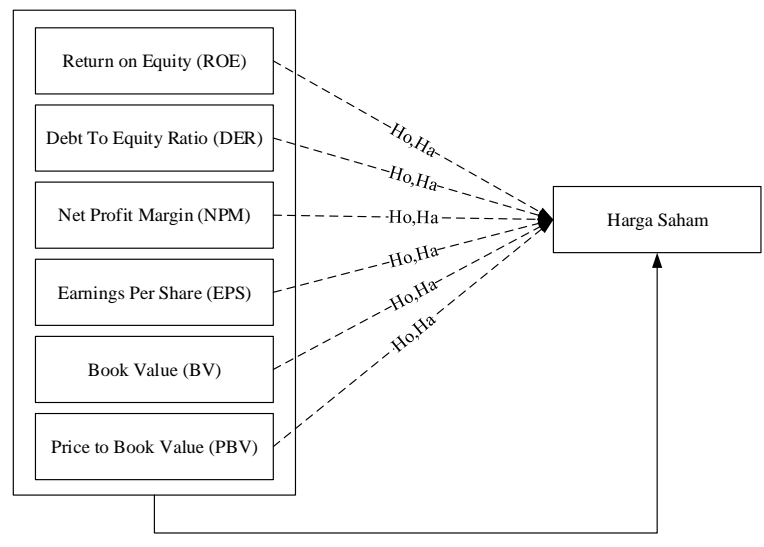

Gambar 1. Kerangka Pemikiran Sumber: Penelitian 2020

Keterangan:

- ROE, DER, NPM, EPS, BV, PBV= Variabel bebas (variabel independen)

- Harga Saham = Variabel terikat (variabel dependen)

Hipotesis untuk mengetahui pengaruh antara ROE, DER, NPM, EPS, BV, dan PBV terhadap Harga Saham dirumuskan sebagai berikut:

1) Ho: diterima, Ha: ditolak, artinya tidak terdapat pengaruh secara parsial dan atau secara simultan ROE, DER, NPM, EPS, BV, dan PBV terhadap Harga Saham.

2) Ha: diterima, Ho: ditolak, artinya terdapat pengaruh secara parsial dan atau secara simultan dari variabel bebas (independen) sebagai variabel pengaruh yaitu Return on Equity (ROE, DER, NPM, EPS, BV, dan PBV terhadap Harga Saham.

\section{Jenis/Sifat Penelitian}

Berdasarkan jenisnya, penelitiian ini tergolong dalam penelitian kuantiitatif yang menggunakan angka-angka sebagai data penelitian. Metode kuantitatif lebih menggambarkan masalah dalam bentuk keterangan hubungan antar variabel dapat berupa hubungan sebab akibat (causal), perbandingan (comparative) atau asosiatif. Sifat hubungan yang diterangkan adalah linear (J.R.Raco, 2010). Variabel dalam penelitian kuantitatif dapat dibedakan menjadi dua yaitu variabel bebas (independent variable) dan variabel terikat (dependent variable) (Priyono, 2008).

\section{Variabel Penelitian}

Penelitian ini terdiri dari variabel bebas (independent variable) yaitu: ROE, DER, NPM, EPS, BV, dan PBV. Sedangkan variabel terikat (dependent variable) yaitu Harga Saham.

\section{Populasi, Sampel, dan Metode Sampling}

Populasi dan sampel yang digunakan dalam penelitian ini adalah perusahaan sektor pertambangan minyak yang terdaftar di Bursa Efek Indonesia Tahun 2014-2018 yaitu APEX, ARTI, BIPI, ELSA, ENRG, ESSA, MITI, MTFN, MEDC, dan RUIS. Metode pengambilan sampel yang digunakan dalam penelitian ini adalah "metode purposive sampling atau judgemental sampling untuk menentukan kriteria khusus" (Priyono, 2008), dengan menggunakan langkahlangkah sebagai berikut:

1) Mengumpulkan data laporan keuangan dan harga saham pada perusahaan sektor pertambangan minyak yang terdaftar di Bursa Efek Indonesia (BEI) Tahun 20142018. 
2) Mengindentifikasi semua karakteristik populasi dengan melakukan studi pendahuluan atau dengan mempelajari berbagai hal yang berhubungan dengan populasi.

3) Menetapkan jumlah populasi berdasarkan kelompok yang sebelumnya telah dilakukan seleksi terhadap populasi yang memenuhi syarat untuk dijadikan sampel dalam penelitian.

\section{Metode dan Alat Pengumpulan Data}

Jenis data yang digunakan dalam penelitian ini adalah data sekunder berupa laporan keuangan yang diperoleh dan diakses melalui situs Bursa Efek Indonesia (BEI). Alat yang digunakan untuk melakukan pengumpulan data pada penelitian ini yaitu menggunakan metode observasi dan analisis terhadap laporan keuangan tahunan masingmasing perusahaan, kemudian dilakukan perhitungan dan analisis menggunakan rasio keuangan.

\section{HASIL DAN PEMBAHASAN}

\section{Uji Regresi Linier Berganda}

Uji regresi linier berganda untuk menganalisis hubungan secara linier antara ROE, DER, NPM, EPS, BV, dan PBV terhadap Harga Saham. Adapun persamaan regresi linier berganda yang menyatakan hubungan antar variabel bebas dan terikat pada penelitian ini sebagai berikut:

$$
Y^{\prime}=a+b_{1} X_{1}+b_{2} X_{2}+\cdots+b_{6} X_{6}
$$

Keterangan:

- $\mathrm{Y}^{\prime}=$ Variabel dependen (nilai yang diprediksikan)

- $\mathrm{a}=$ Konstanta

- $\mathrm{b}_{1}, \mathrm{~b}_{2}, \ldots, \mathrm{b}_{6}=$ Koefisien regresi (nilai peningkatan ataupun penurunan)

- $\mathrm{X}_{1}, \mathrm{X}_{2}, \ldots, \mathrm{X}_{6}=$ Variabel independen
Tabel 1.Uji Regresi Linier Berganda Coefficients $^{\mathrm{a}}$

\begin{tabular}{|c|c|c|c|c|c|}
\hline \multirow[b]{2}{*}{ Model } & \multicolumn{2}{|c|}{$\begin{array}{l}\text { Unstandardized } \\
\text { Coefficients }\end{array}$} & \multirow{2}{*}{$\begin{array}{c}\begin{array}{c}\text { Standar } \\
\text { dized } \\
\text { Coeffici } \\
\text { ents }\end{array} \\
\text { Beta }\end{array}$} & \multirow[b]{2}{*}{$\mathrm{t}$} & \multirow[b]{2}{*}{ Sig. } \\
\hline & $\mathrm{B}$ & $\begin{array}{l}\text { Std. } \\
\text { Error }\end{array}$ & & & \\
\hline 1 (Constant) &,- 310 & ,615 & &,- 505 & ,616 \\
\hline ROE & ,118 & ,044 & ,224 & 2,677 &, 010 \\
\hline DER &,- 136 & ,045 &,- 225 & $-3,057$ & ,004 \\
\hline NPM &,- 085 & ,032 &,- 175 & $-2,688$ &, 010 \\
\hline EPS &,- 044 & ,029 &,- 079 & $-1,510$ & , 138 \\
\hline BV & ,557 & ,084 & ,373 & 6,601 & ,000 \\
\hline PBV & ,801 & ,044 & 1,085 & 18,044 & ,000 \\
\hline
\end{tabular}

Hubungan antara ROE, DER, NPM, EPS, BV, dan PBV dengan harga saham pada tabel 1 diatas sebagai berikut:

1) Pada variabel ROE, BV, dan PBV diperoleh nilai koefisien regresi ROE sebesar 0,118, BV sebesar 0,557, dan PBV sebesar 0,801 bernilai positif artinya terjadi hubungan positif antara ROE, BV, dan PBV terhadap harga saham.

2) Pada variabel DER, NPM, dan EPS diperoleh nilai koefisien regresi DER sebesar -0,136, NPM sebesar-0,085, dan EPS sebesar -0,044 bernilai negatif artinya terjadi hubungan negatif antara DER, NPM, dan EPS terhadap harga saham.

\section{Uji Hipotesis Parsial (Uji t)}

Hubungan antara ROE, DER, NPM, EPS, BV, dan PBV dengan harga saham pada tabel 1 sebagai berikut:

1) Pada variabel ROE, DER, NPM, BV, dan PBV diperoleh nilai signifikansi (Sig.) ROE 0,010 < 0,025, DER 0,004 < 0,025, NPM 0,010 < 0,025, BV 0,000 < 0,025, dan PBV 0,000 < 0,025 maka Ho: ditolak, Ha: diterima, yaitu terdapat pengaruh ROE, DER, NPM, 
BV, dan PBV terhadap harga saham secara parsial.

2) Pada variabel EPS diperoleh nilai signifikansi (Sig.) 0,138>0,025 maka Ho: diterima, Ha: ditolak, yaitu tidak terdapat pengaruh EPS terhadap harga saham secara parsial.

\section{Uji Hipotesis Simultan (Uji F)}

Uji hipotesis simultan (uji F) untuk mengetahui pengaruh ROE, DER, NPM, EPS, BV, dan PBV terhadap Harga Saham secara simultan.

Tabel 2. Uji Hipotesis Simultan (Uji F)

\begin{tabular}{|l|r|r|r|r|r|}
\hline \multicolumn{7}{|c|}{ ANOVA $^{\text {a }}$} \\
Model & $\begin{array}{r}\text { Sum of } \\
\text { Squares }\end{array}$ & df & $\begin{array}{c}\text { Mean } \\
\text { Square }\end{array}$ & \multicolumn{1}{c|}{ F } & Sig. \\
\hline 1 Regression & 57,268 & 6 & 9,545 & 77,255 &, $000^{\mathrm{b}}$ \\
Residual & 5,312 & 43 &, 124 & & \\
Total & 62,580 & 49 & & & \\
\hline
\end{tabular}

a. Dependent Variable: Harga_Saham

b. Predictors: (Constant), PBV, ROE, EPS, NPM, BV, DER

Sumber: Penelitian 2020

Hubungan antara ROE, DER, NPM, EPS, BV, dan PBV dengan harga saham pada tabel 3 diperoleh nilai signifikansi (Sig.) $0,000<0,05$, maka Ho: ditolak, Ha: diterima, yaitu terdapat pengaruh $\mathrm{ROE}$, DER, NPM, EPS, BV, dan PBV terhadap harga saham secara simultan.

\section{Uji Koefisien Determinasi $\left(\mathbf{R}^{\mathbf{2}}\right)$}

Uji koefisien determinasi $\left(\mathrm{R}^{2}\right)$ untuk memprediksi seberapa besar kontribusi pengaruh yang diberikan oleh ROE, DER, NPM, EPS, BV, dan PBV secara simultan (bersama-sama) terhadap Harga Saham.

Tabel 3. Uji Koefisien Determinasi $\left(\mathbf{R}^{2}\right)$ Model Summary

\begin{tabular}{|l|c|r|r|c|}
\hline Model & $\mathrm{R}$ & $\begin{array}{c}\mathrm{R} \\
\text { Square }\end{array}$ & $\begin{array}{c}\text { Adjusted R } \\
\text { Square }\end{array}$ & $\begin{array}{c}\text { Std. Error of the } \\
\text { Estimate }\end{array}$ \\
\hline 1 &, $957^{\mathrm{a}}$ &, 915 &, 903 &, 351 \\
\hline
\end{tabular}

Dari tabel 3, nilai koefisien determinasi $\left(\mathrm{R}^{2}\right)$ sebesar 0,915 yaitu ROE, DER, NPM, EPS, BV, dan PBV berpengaruh sangat kuat pada interval 0,80-1,000 (Sugiyono, 2009 dalam Nuryani, 2014) terhadap Harga Saham sebesar $91,5 \%$, dan sisanya 8,5\% dipengaruhi oleh variabel lain. Sedangkan Standar Error of the Esimate (SEE) untuk mengukur banyaknya kesalahan dari model regresi dalam memprediksi nilai Harga Saham (Y) sebesar 0,351 atau Rp.0,315 (satuan harga saham).

\section{KESIMPULAN}

Dari pembahasan hasil analisis regresi maka dapat ditarik kesimpulan dari penelitian ini yaitu: Berdasarkan uji t ROE, BV, dan PBV berpengaruh positif sedangkan DER dan NPM berpengaruh negatif terhadap harga saham. Berdasarkan uji hipotesis simultan (uji F) variabel $\mathrm{ROE}(\mathrm{X} 1), \operatorname{DER}(\mathrm{X} 2)$, NPM(X3), EPS(X4), BV(X5), dan PBV(X6) berpengaruh positif terhadap harga saham (Y). Berdasarkan uji koefisien determinasi $\left(\mathrm{R}^{2}\right)$ manajemen perusahaan dalam memprediksi kenaikan harga saham (Y) dipengaruhi sangat kuat oleh variabel ROE(X1), DER(X2), NPM(X3), BV(X5), dan PBV(X6) sebesar 91,5\% dan dipengaruhi oleh variabel lain yang tidak dimasukkan didalam penelitian ini sebesar $8,5 \%$.

Dari pengambilan kesimpulan berdasarkan hasil penelitian diatas maka sebagai saran yaitu: Penelitian ini diharapkan dapat bermanfaat bagi manajemen perusahaan sektor pertambangan minyak sebagai bahan masukan dalam mengevaluasi kinerja harga saham berhubungan dengan variabel rasio keuangan ROE, DER, NPM, BV, dan PBV; Penelitian ini dapat digunakan sebagai referensi atau rujukan pustaka dalam penyusunan karya ilmiah sejenis maupun karya ilmiah lainnya bagi peneliti yang ingin melakukan penelitian dengan tema sejenis dengan fokus studi pada emiten 
pertambangan minyak; Peneliti selanjutnya dapat mengetahui kinerja masing-masing emiten secara lebih spesifik dibatasi hanya pada emiten tertentu dengan fokus penelitian pada kegiatan operasional perusahaan selama satu tahun penuh, yang dapat dilakukan dengan menggunakan variabel sejenis atau dengan variabel lainnya.

\section{DAFTAR PUSTAKA}

Apsara, R. H., \& Indriani, A. (2017). Analisis Pengaruh Crude Oil Price, Earning Per Share, Price To Book Value, Return On Assets Dan Debt To Equity Ratio Terhadap Harga Saham Perusahaan Batubara Yang Terdaftar Di Bursa Efek Indonesia Periode 2012-2016. Diponegoro Journal Of Management, 6(4), 1-13. Retrieved from http://eprints.undip.ac.id/57358/1/03_ APSARA.pdf

cermati.com. (2017). Faktor-Faktor Penyebab Naik Turunnya Harga Saham. Retrieved from cermati.com website:

https://www.cermati.com/artikel/fakto r-faktor-penyebab-naik-turunnyaharga-saham-apa-saja

Ekawati, Y. (2017). Pengaruh Return On Asset (ROA), Debt To Equity Ratio (DER), Price To Book Value (PBV), Dan Current Ratio (CR) Terhadap Harga Saham Perusahaan Manufaktur Subsektor Pertambangan Batubara Dan Minyak Mentah \& Produksi Gas Alam Yang Terdaftar Di Bursa Efek Ind. Simki-Economic, 01(03), 1-11.

Gumilang, R. C., Hidayat, R. R., \& NP, M. G. W. E. (2014). Pengaruh Variabel Makro Ekonomi, Harga Emas Dan Harga Minyak Dunia Terhadap Indeks Harga Saham Gabungan (Studi Pada Bursa Efek Indonesia Periode 20092013). Jurnal Administrasi Bisnis (JAB), 14(2), 1-9. Retrieved from administrasibisnis.studentjournal.ub.ac .id\%0A1

Hikmah. (2018). Pengaruh Rasio Profitabilitas Terhadap Harga Saham Perusahaan Sub Sektor Minyak Dan Gas Bumi Yang Terdaftar Di BEI. Journal of Management \& Business, 2(1), 56-72.

Istanti, E. (2015). Analisis Net Profit Margin, Return On Asset dan Return On Equity dalam Mengevaluasi Kinerja Keuangan pada PT. Indospring Tbk Periode 2007-2011. E-Jurnal Manajemen Branchmarck, 1(2), 1-18. https://doi.org/10.1017/CBO97811074 15324.004

J.R.Raco. (2010). Metode Penelitian Kuantitatif (2010th ed.; C. R. Semiawan, Ed.). Jakarta, Indonesia: PT Gramedia Widiasarana.

Moeljadi. (2017). Financial Ratio Return On Equity Dengan Net Profit Margin Sebagai Variabel Moderator. JPSB, 5(2), 133-160.

Mulia, F. H., \& Nurdhiana. (2010). Pengaruh Book Value ( BV ), Price to Book Value ( PBV ), Earning Per Share ( EPS ), dan Price Earning Ratio ( PER ) Terhadap Harga Saham Perusahaan Food and Beverage yang Terdaftar di Bursa Efek Indonesia Tahun 20072010. Jurnal.Widyamanggala.Ac.Id, 1-19. Retrieved from http://jurnal.widyamanggala.ac.id/inde x.php/wmkeb/article/view/53

Novia. (2018). Mengenal Teori Signaling Dalam Struktur Modal \& Hubungannya dengan Rasio Keuangan. Retrieved from jurnal.id website:

https://www.jurnal.id/id/blog/2018mengenal-teori-signaling-dalamstruktur-modal/

Nuryani, E. (2014). Hubungan Intensitas Mengakses Facebook Dengan Motivasi Belajar Siswa Sma Negeri 2 
Tenggarong Seberang. Jurnal Ilmu Komunikasi, 2(3), 178-192.

Pertiwi, D. S. (2018). Saham Minyak Terpeleset Penurunan Harga Komoditas. Retrieved from investasi.kontan.co.id website: https://investasi.kontan.co.id/news/sah am-minyak-terpeleset-penurunanharga-komoditas

Priyono. (2008). Metode Penelitian Kuantitatif (Edisi Revi; T. Chandra, Ed.). Jl. Taman Pondok Jati J 3, Taman Sidoarjo Telp/fax: $031-7871090$ Email : zifatama@gmail.com: Zifatama Publishing.

Ramadhana, A. A., Sjahruddin, H., \& Purnomo, S. H. (2018). Pengaruh Kinerja Keuangan Terhadap Harga Saham. Jurnal Organisasi Dan Manajemen, (1), 47-65. Retrieved from

https://www.researchgate.net/publicati
on/327871411\%0APENGARUH

Ramli, V. N. dan I. (2016). Krisis Ekonomi Krisis Politik Dunia Dan IHSG. Jurnal Ekonomi, XXI(01), 61-75.

Safitri, T. A. (2013). Asimetri Informasi Dan Underpricing. Jurnal Dinamika Manajemen, 4(1), 1-9. https://doi.org/10.15294/jdm.v4i1.241 9

Takarini, N., \& Hendrarini, H. (2011). Rasio Keuangan Dan Pengaruhnya Terhadap Harga Saham. Journal of Business and Banking, 1(2), 93-104.

Wardani, S. S., Diana, N., \& Mawardi, M. C. (2015). Pengaruh Asimetri Informasi Keuangan, Accrual Terhadap Tingkat Return Saham Pada Perusahaan Go Publik. Universitas Islam Malang, 5870. 